TEME, г. XLIV, бр. 2, април - јун 2020, стр. 403-422

\begin{tabular}{lr}
\hline Оригинални научни рад & https://doi.org/10.22190/TEME180927033D \\
Примљено: 27.9.2018. & UDK 378.18:316.722
\end{tabular}

Ревидирана верзија: 17. 2. 2019.

Одобрено за штампу: 15. 4. 2020.

\title{
СОЦИОДЕМОГРАФСКЕ ДЕТЕРМИНАНТЕ КАО ПРЕДИКТОРИ ИНТЕРКУЛТУРАЛНЕ ОСЕТЉИВОСТИ СТУДЕНАТА
}

\author{
Игор Ђурић ${ }^{1}$, Далиборка Поповић ${ }^{2}$, Александра Анђелковић ${ }^{3 *}$ \\ ${ }^{1}$ Универзитет у Приштини са привременим седиштем \\ у Косовској Митровици, Филозофски факултет, Србија \\ ${ }^{2}$ Државни универзитет у Новом Пазару, Србија \\ ${ }^{3}$ Универзитет у Нишу, Педагошки факултет Врање, Врање, Србија \\ *aleksandraa@pfvr.ni.ac.rs
}

\begin{abstract}
Апстракт
Друштвена хетерогеност, као глобална парадигма, представља снажну полугу иницијативе развијања и проучавања интеркултуралне осетљивости појединаца и група. У последњим декадама интеркултуралност, интеркултуралне компетенције и интеркултурална осетљивост део су бројних истраживања у различитим областима. Интеркултурална осетљивост студената налази се у средишту истраживања овог рада и разматрана је кроз призму социодемографских детерминанти. У методолошком делу рада представљени су резултати истраживања спроведеног на узорку од 452 студента са четири универзитета у Србији. Као инструмент коришћена је Скала интеркултуралне осетљивости Intercultural Sensitivity Scale - ISS. Циљ истраживања је утврђивање степена развијености интеркултуралне осетљивости студената у односу на поједине социодемографске варијабле. Циљ истраживања је утврђивање степена интеркултуралне осетљивости студената у односу на поједине социодемографске варијабле. Резултати су показали да студенти Државног универзитета у Новом Пазару процењују да поседују виши ниво интеркултуралне осетљивости на појединим димензијама Скале. Просечан број чланова домаћинства идентификован је као варијабла са негативном корелацијом на интеркултуралну осетљивост студената. У закључку је указано на неопходност промене приступа у развијању интеркултуралне осетљивости студената, која се огледа у трагању за одговарајућим начинима рада којима се обогаћују њихова искуства и утиче на промене друштвеног и образовног контекста.
\end{abstract}

Кључне речи: скала интеркултуралне осетљивости, културолошке разлике, социодемографске варијабле, студенти. 


\title{
SOCIO-DEMOGRAPHIC DETERMINANTS AS PREDICTORS OF INTERCULTURAL SENSITIVITY OF STUDENTS
}

\begin{abstract}
Societal heterogeneity, as a global paradigm, represents a strong leverage of the initiative for the development and research of an individual's and groups' intercultural sensitivity. In the last few decades, interculturality, intercultural competencies and intercultural sensitivity have been the topic of many researches in various fields. Students' intercultural sensitivity is the focus of this paper and it is seen through the prism of socio-demographic determinants. The results of the research which was done on the sample of 452 students from four universities in Serbia are shown in the methodological part of the paper. The instrument used was the Intercultural Sensitivity Scale - ISS. The goal of the research is to determine the degree of the development of the students' intercultural sensitivity in relation to certain socio-demographic variables. Results have shown that the students from the State University of Novi Pazar are estimated to have the highest level of intercultural sensitivity in certain dimensions of the scale. The average number of household members, was identified as a variable with a negative correlation on the students' intercultural sensitivity. The conclusion points out to the necessity of change in the approach to the development of the students' intercultural sensitivity approach, which is reflected in the research in that it should point to adequate work approaches that enrich their experience and influence the changes in social and educational context.
\end{abstract}

Key words: intercultural sensitivity scale, cultural differences, sociodemographic variables, students.

\section{УВОД}

Данашња друштва, значајније него икада, обележава хетерогеност којом су условљене потребе настајања и изградње различитих способности појединаца. „Пре више од две декаде догодила се експлозија публикација у хуманистичким и друштвеним наукама" у којима је испитивање „културолошке различитости” (Oullet, 2002) постављено као истраживачки проблем, а настале друштвене тенденције непрестано се одражавају на област образовања. У том смислу, расправе о културолошкој различитости чији су приоритети развијање свести о њиховом уважавању пред образовни систем и његове носиоце постављају сложене задатаке. У потрази за најпогоднијим моделима развоја интеркултуралне компетентности појединаца, појавили су се „многобројни образовни одговори на питање културолошких и верских различитости" (Oullet, 2002, p. 146). У бројним радовима (Deardorff, 2004; Deardorff, 2006; Deardorff, 2011; Golub, 2014; Park, 1924; Piršl, 2014) специфичан друштвени контекст помиње се не само као појмовна одредница интеркултуралности већ и као варијабла од изузетног утицаја на развој интеркултуралности појединаца. Пиршл (Piršl, 2014) потврђује да треба узети у обзир и специфичан 
културални (друштвени) контекст приликом разумевања утицаја појединих димензија на одређење не само појма већ и модела интеркултуралних компетенција. Као циљ развијања интеркултуралних компетенција поједини аутори издвајају унапређивање односа и успостављање међусобног разумевања између чланова различитих култура и социјалних група (Golub, 2014, str. 77), при чему се посебно истиче да ниво интеркултуралне компетентности у значајној мери детерминише односе и понашања међу људима који припадају различитим друштвеним групама. „Што су интеркултуралне компетенције појединца скромније, то је снажнија социјална дистанца коју он исказује према припадницима других друштвених скупина" (Boneta, Ivković, Lacmanović, 2013, str. 482). Под појмом соиијална дистанца Роберт Парк (Park, 1924, p. 339) подразумева „нивое разумевања и интимности који карактеришу личне и друштвене односе".

Неоспорна је тврдња да се интеркултуралност може посматрати као врста споне и могућност квалитетнијег повезивања појединца и друштвене средине, као и то да је развој интеркултуралних компетенција процес који није лако довршити, већ учестало изискује обнову и надградњу. Анализе показују (Deardorff, 2006) да међу ауторима не постоји сагласност по питању терминолошког одређења интеркултуралне компетентности, као и да варијације настају у зависности од науке или дисциплине у чијем средишту проучавања се налази интеркултуралност. Поменута ауторка, наглашава да истраживачи који се баве социјалним радом користе термин културолошке компетениије, док се у техници чешће употребљавају глобалне компетенције. Такође, Дирдорф (Deardorff, 2011, p. 65) указује на то да се, поред осталог, интеркултуралне компетенције и различитости све значајније повезују са учењем код студената, док развој интеркултуралних компетенција заузима, и наставиће да заузима, све већу улогу у будућности, с обзиром на разноликост америчког друштва.

Различити приступи и специфичне анализе аутора стварају различите димензије и моделе интеркултуралних компетенција. Фантини (Fantini, 2009) међу бројним терминима који су у употреби за појашњење појма интеркултуралности наводи мултикултурализам, међукултурално прилагођавање, интеркултуралну осетљивост, међукултуралну комуникацију и глобално држављанство. Богатство терминолошких појмова не изненађује јер су интеркултуралне компетенције комплексан конструкт, који укључује више од једне компонете, при чему је наглашено да знања о интеркултуралности не гарантују интеркултуралну компетентност, већ је неопходна укљученост когнитивних вештина за њихову интериоризацију у уверења и понашања (Deardorff, 2004, p. 203). Фантини (Fantini, 2000) у свом пилот-документу, намењеном критичком сагледавању интеркултуралних циљева, издваја пет различитих димензија интеркултуралних 
ставова, са особеним ајтемима, а то су: знања, вештине, ставови, свесност и стручно познавање језика. У изворима на руском језику (Kornienko, Logašenko, 2015; Erofeeva, 2017; Černяk, 2015) интеркултурална осетљивост такође се посматра као компонента интеркултуралне компетентности, која доприноси успешној интеракцији у мултиетничком окружењу. Према мишљењу неких аутора (Kornienko, Erofeeva, 2017, str. 279-280), овај појам подразумева специфичан сензибилитет личности за културне и етничке различитости, као и способност уважавања одређених вредности својствених различитим нацијама и етничким групама. Истичући да интеркултурална осетљивост представља важан услов за ефикасну и конструктивну интеракцију, Логашенко (Logašenko, 2015) ипак закључује да развијена интеркултурална осетљивост, сама по себи, не гарантује достизање интеркултуралне компетентности индивидуе. У том смислу, већу вредност имају заједнички циљеви, морални принципи, као и спремност појединца на интеркултуралну интеракцију (Ibid, str. 85).

Примесе емоционалне компоненте, уопштено гледано, огледају се у развијеној способности за осетљивост појединаца према особама другачијег културолошког порекла и представљају основу интеркултуралних компетенција, које су неопходне за грађење интеркултуралних односа (Hrvatić \& Piršl, str. 2007). Компетенције за интеркултурану комуникацију у интеркултуралним друштвима се стога дефинишу као способност ефикасног и на одговарајући начин оствареног понашања у комуникацији, којима се подржава међусобни културални идентитет или идентитет у културално разноврсном окружењу (Chen \& Starosta, 1999, p. 28).

У оквирима интеркултуралних компетенција и интеркултуралне осетљивости, интеркултурална комуникација помиње се као саставни део теоријских и истраживачких радова. У новијим истраживања (Sarwari \& Abdul Wahab, 2017) указује се на разлике између интеркултуралне осетљивости, која омогућава појединцима иницирање контаката са људима из различитих култура, и интеркултуралне комуникацијске компетенције, путем које се успоставља интеракција и успешније управља потенцијалним изазовима за сарадњу и заједничко деловање. Као три кључне компоненте компетенција интеркултуралне комуникације, издвојене су: интеркултурална осетљивост (афективни процес), интеркултурална свесност (когнитивни процес) и интеркултурална сналажљивост (бихевиорални процес), која подразумева вербалне и невербалне вештине потребне за ефикасну интеркултуралну интеракцију (Chen \& Starosta, 1999).

У трагању за јасном терминологијом о интеркултуралности, аутори Чен и Староста (Chen \& Starosta, 2000) издвојили су три блиска, али засебна концепта: интеркултурану осетљивост, интеркултуралну свесност и компетенције за интеркултуралну комуникацију. 
Свака од наведених димензија садржи низ компоненти. Поменути аутори иначе су познати по изузетном доприносу у дефинисању појмова и концепта интеркултуралности, као и стварању једног од најчешће коришћених инструмената за испитивање интеркултуралне осетљивости Скале за интеркултуралну осетљивост - ISS Intercultural Sensitivity Scale, која садржи 24 ајтема. На подручју Немачке потврђена је валидност ISS скале (Fritz \& Möllenberg, 2002), док је у налазима појединих аутора (Petrović, Starčević, Chen, Komneninić, 2015) за територију Србију предложена одређена модификација поменутог инструмента.

Временом су настали и различити модели (према: Deardorff, 2011, p. 65) који су коришћени да уоквире поједине аспекте интеркултуралних компетенција, међу којима су Бенетов Развојни модел интеркултуралне осетљивости (Bennett's Developmental Model of Intercultural Sensitivity 1993), Модел интеркултуралне зрелости Кинга и Бакстера Маголде (King and Baxter Magolda's interculturalmaturity model, 2005) и Кросов међукултурални континуум (Cross's cross-cultural continuum, 1988). Бенетонов Развојни модел интеркултуралне осетљивости (Development Model of Intercultural Sensitivity - DMSI) заснован је на два суштински различита погледа на свет - етноцентричног и етнорелативног (према: Deardorff, 2011, p. 68).

\section{Интеркултурална осетљивост у образовном контексту}

Пораст научног интересовања за проблематику интеркултуралног образовања условљен је сазнањем о значају и потреби развијања међукултурне компетентности младих. У таквим околностима интеркултурна осетљивост јавља се као једна од важних компоненти и представља карактеристику личности, која доприноси успостављању толерантних и оптималних односа са представницима различитих култура. У образовном контексту, такође се издвајају потребе развоја интеркултуралних компетенција наставника, које настају због све изразитије различитости ученика у учионицама. Питање интеркултуралности постало је есенцијални део разматрања и код кандидата који се припремају за наставнички позив, тако је једно од основних питања овог рада сагледавање предиктора за развијање интеркултуралности код студаната како би се сходно томе деловало у правцу унапређивања интеркултуралности и компетенција за деловање у овој области.

У литератури се (Bok, 2006, p. 248) као препорука и најбољи начин рада са студентима издваја међусобно учење студената, и то не похађањем часова о интеркултуралности, већ учешћем у просторијама за дискусију, конверзацијама у току оброка и другим групним активностима у кампусу. Инострани филмови такође представљају могућност стварања другачијег погледа на свет, посебно ако су ком- 
биновани са дискусијом и рефлексивним радом на садржајима који се тичу културног миљеа у којем се дешава радња. На тај начин је могуће директно сагледавати и анализирати интеркултуралну осетљивост студената, док се индиректни показатељи који су у вези са студентским перцепцијама интеркултуралног учења и развојем интеркултуралних компетенција могу прикупити кроз интервјуе и фокус-групе (Deardorff, 2011, p. 72).

Закључци аутора који се баве интеркултуралном осетљивошћу и компетенцијама студента говоре у прилог чињеници да већина иностраних студената у кампусима не показује висок ниво интеркултуралне компетентности. Промишљања о томе како се интеркултуралне компетенције могу развијати код студената резултирала су идентификовањем две могућности: кроз курикулум и кроз кокурикуларне активности (Deardorff, 2011, p. 69). У том смислу, ауторка даље наводи да је потребно интеркултуралне компетенције апострофирати кроз бројне предмете на студијама, посебно кроз тзв. STEM Science, Technology, Engineering and Mathematics, али је пре свега потребно да факултети међусобно разумеју у потпуности како овај концепт интегрисати у постојеће курикулуме. Аутори са простора Србије (Petrović, Gošović, Marković 2016. str. 34) указују на то да се:

„Интеркултуралне компетенције не спомињу као део наставничких компетенција које будући наставници треба да стекну иницијалним образовањем, већ је наглашена само једна њихова одлика, а то је разумевање културног контекста у којем се одвија процес васпитања и образовања". Такође се у радовима наводе и лични, опструирајући, утицаји на унапређивање међународне толеранције и сарадње младих:

„Неразумевање, предрасуде, неповерење и непријатељство према онима који не припадају истом националном, етничком или религијском ентитету отежавају поверење, сарадњу, уважавање, толеранцију, пријатељство и уопште прихватање различитости" (Jovanović i Kačapor, 2016, str. 353). Ради сагледавања програмских садржаја усмерених ка развијању интеркултуралних компетенција студената, неопходне су студиозније анализе интеркултуралне осетљивости студената, које су условљене бројним предикторима.

\section{МЕТОДОЛОГИЈА}

Претходна истраживања недвосмислено показују да је, при анализи фактора који условљавају развој интеркултуралне осетљивости студената, значајно разматрање друштвеног контекста појединаца, којим се ствара вредносни систем одређене заједнице, утиче на појединце и даје основа за квалитет образовне политике. 
Из поменутих разлога, циљ истраживања јесу релације процена студената између степена развијености интеркултуралне осетљивости и појединих социодемографских варијабли. Полазећи од истраживачког циља, задаци су били усмерени на: 1) испитивање интеркултуралне осетљивости студената на укупном узорку студената, кроз пет димензија: Ангажованост у интеракцији, поштовање културолошких разлика, Самопоуздање у интеракцији, Задовољство у интеракцији и Усредсређеност у интеракцији; 2) испитивање унакрсног односа и статистичке значајности дефинисаних варијабли из друштвеног контекста студената са димензијама скале интеркултуралне осетљивости.

Истраживачки узорак: Истраживање је спроведено на пригодном узорку од 452 студента са четири Универзитета у Србији. У даљем тексту, кроз табеларни приказ дата је структура узорка према независним варијаблама, а то су: универзитет којем студенти припадају, промена места боравка у току студија, број чланова у породици студената, стандард домаћинства и место становања током студија. У Табели 1 дат је приказ расподеле узорка студената према наведеним варијаблама.

Табела 1. Социодемографске карактеристике узорка

\begin{tabular}{lr}
\hline & $\mathrm{N}=452$ \\
\hline Универзитет, n (\%) & $141(31,2)$ \\
Ниш & $103(22,8)$ \\
Крагујевац & $97(21,5)$ \\
Нови Пазар & $111(24,6)$ \\
Косовска Митровица & $119(26,5)$ \\
\hline Промена места боравка током студија, $\mathrm{n}(\%)$ & $330(73,5)$ \\
\hline Да & \\
Не & $279(61,7)$ \\
\hline Стандард домаћинства у односу на просечно домаћинство & $49(10,8)$ \\
у Србији, $\mathrm{( \% )}$ & $34(7,5)$ \\
\hline У просеку & $90(19,9)$ \\
Испод просека & $186(41,5)$ \\
Изнад просека & $183(40,8)$ \\
Не знам / Не могу да оценим & $79(17,6)$ \\
\hline Место становања током студирања, $\mathrm{n}(\%)$ & $4,71 \pm 1,36$ \\
\hline Породични дом & \\
Подстанар & \\
Студентски дом & \\
\hline Просечан број чланова у породици, M \pm SD & \\
\hline
\end{tabular}

Највећи број учесника истраживања је са: Универзитета у Нишу $(31,2 \%)$, затим Универзитета у Приштини са привременим седиштем у Косовској Митровици (24,6\%), Универзитета у Крагујевцу $(22,8 \%)$ и Универзитета у Новом Пазару $(21,5 \%)$. 
У Табели 1 уочава се да већи део студената $(73,5 \%)$ није мењао место боравка током студија, док се мањи део узорка изјаснио потврдно (26,5\%), те да се број чланова у породицама студената креће од 1 до 10 (М 4,71).

Више од половине студената $(61,7 \%)$ сматра да је стандард домаћинства у којем живе просечан у односу на просек у Србији, 19,9\% испитаника није сигурно у вези са оваквом проценом или не зна да процени стандард своје породице, $10,8 \%$ изјаснило се да живе у домаћинствима испод просека, а свега 7,5\% изнад просека. Од укупног броја анкетираних студената, мање од једне половине (41,5\%) живи у породичном дому, скоро исто толико живе као подстанари у изнајмљеном стану (40,8\%), а њих $17,6 \%$ је у студентском дому.

Ток истраживаға и инструмент: Истраживање је спроведено у новембру и децембру 2017. године са студентима Универзитета у Крагујевцу, Нишу, Новом Пазару и Косовској Митровици. За прикупљање података коришћена је скала Intercultural Sensitivity Scale ISS (Chen \& Starosta, 2000), за коју је урађена факторска анализа. У Сакли се налазе 24 тврдње намењене истраживању концепта интеркултуралне осетљивости, које су груписане у пет димензија: ангажованост у интеракцији, поштовање културолошких разлика, самопоуздање у интеракцији, задовољство у интеракцији и усредсређеност у интеракцији.

Поузданост инструмента: Ради потврђивања или одбацивања резултата добијених Kaiser-Guttmanov-им критеријумом, факторска структура проверена је и дијаграмом превоја (screeplot), којим се недвосмислено показује да треба издвојити пет фактора.

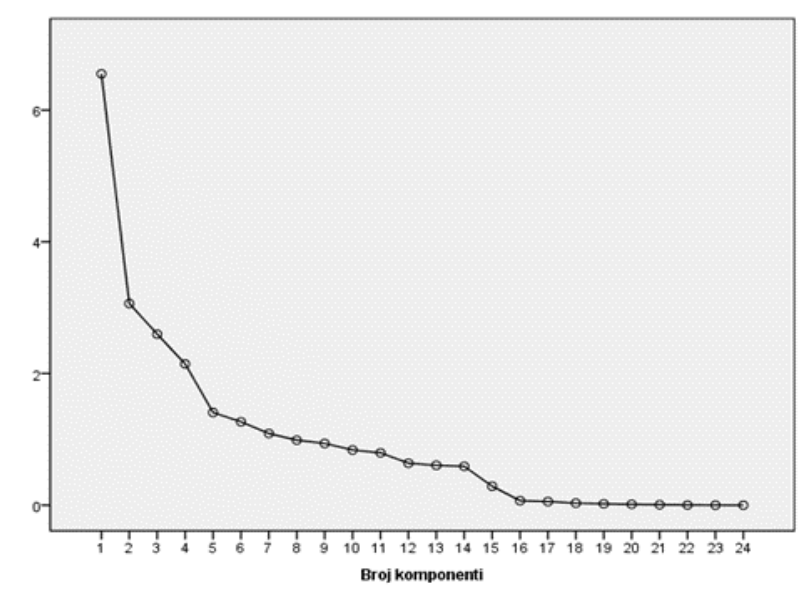

Графикон 1. Дијаграм превоја (Scree Plot) 
Ротирана матрица потврдила је припадност ајтема димензијама конструктора. Ротирајући 24 ајтема, они су распоређени у пет димензија. Факторска засићења су висока и само код неколико ајтема она су изнад 0,3 и на неком другом фактору. Међутим, засићења на другим факторима врло су близу вредности од 0,3 , а на главним факторима висока, те су такви резултати прихватљиви. Резултати су приказани у Табели 2.

Табела 2. Факторска оптерећења за излучене факторе

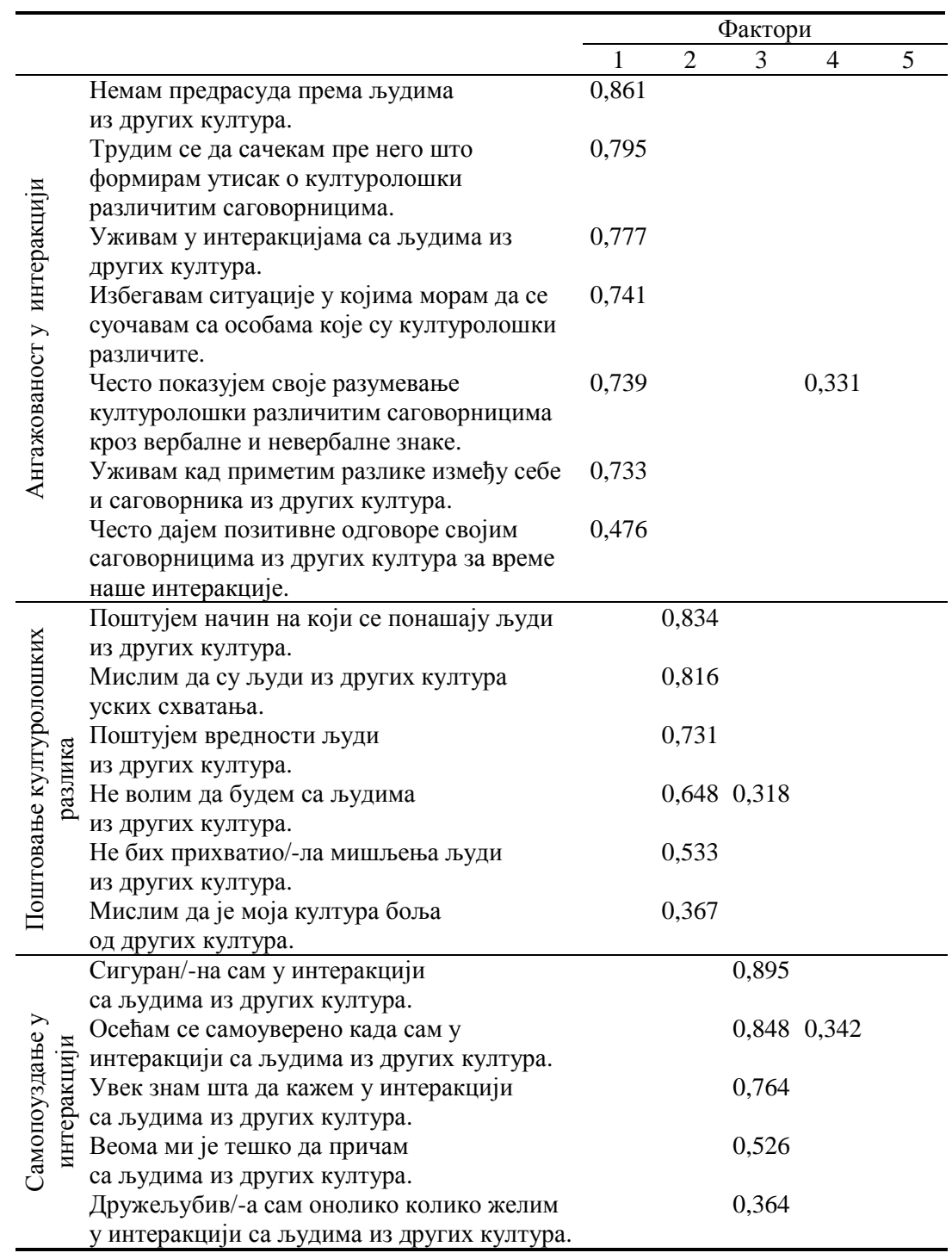




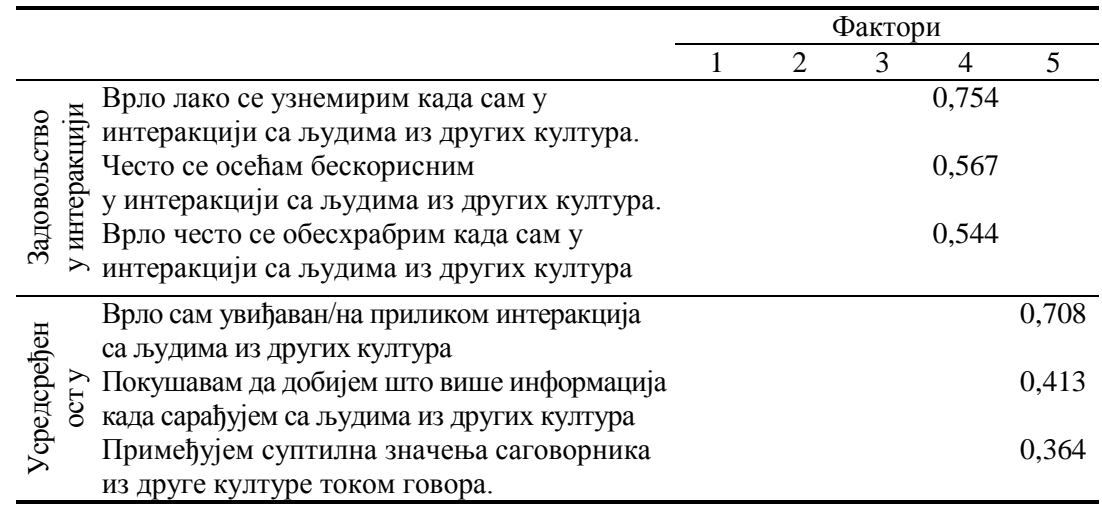

Поузданост како целе скале $(0,890)$ и сваке од појединачних димензија имају високе вредности и крећу се од 0,820 до 0,945. Прихватљиве вредности Кромбах алфа коефицијента су изнад 0,7 , те је закључак да Скала интеркултуралне осетљивости показује високу поузданост на одабраном узорку студената из Србије.

\section{РЕЗУЛТАТИ ИСТРАЖИВАЬА}

У Табели 3 приказане су просечно остварене вредности на свих пет димензија Скале интеркултуралне осетљивости.

Табела 3. Просечне остварене вредности на димензијама скале културне осетьивости

\begin{tabular}{lcccc}
\hline & Мин. & Макс. & M & SD \\
\hline Задовољство у интеракцији & 1,00 & 5,00 & 4,20 & 0,68 \\
Поштовање културолошких разлика & 1,83 & 5,00 & 4,16 & 0,58 \\
Ангажованост у интеракцији & 1,43 & 5,00 & 3,80 & 0,52 \\
Самопоуздање у интеракцији & 1,60 & 5,00 & 3,75 & 0,58 \\
Усредсређеност у интеракцији & 1,67 & 5,00 & 3,65 & 0,61 \\
\hline
\end{tabular}

Према добијеним подацима, испитаници имају највиши скор на димензији Задовољство у интеракцији $(\mathrm{M}=4,20)$, затим следе: поштовање културолошких разлика $(\mathrm{M}=4,16)$, Ангажованост у интеракцији $(\mathrm{M}=3,80)$. Димензије са најнижим скоровима јесу самопоуздање у интеракцији $(\mathrm{M}=3,75)$ и уредсређеност у интеракцији $(\mathrm{M}=3,65)$. Треба нагласити да све димензије имају просечану оцену изнад 3 , што указује на релативно високе резултате на свим димензијама.

У наредном делу рада приказана су унакрсна испитивања независних истраживачких варијабли: универзитет којем припадају студенти, промена места боравка у току студија, број чланова у породици студената, стандард домаћинства и место становања током студија са 
димензијама Скале интеркултуралне осетљивости. Једнофакторском анализом варијансе (ANOVA) испитано је да ли се мишљења испитаника који припадају различитим универзитетима статистички значајно разликују на димензијама Скале интеркултуралне осетљивости.

Табела 4. Димензије скале интеркултуралне осетьивости и повезаност са Универзитетом студената

\begin{tabular}{|c|c|c|c|c|c|c|}
\hline & & $\begin{array}{c}\text { Ангажованост } \\
\text { y } \\
\text { интеракцији }\end{array}$ & $\begin{array}{c}\text { Поштовање } \\
\text { културо- } \\
\text { лошких } \\
\text { разлика } \\
\end{array}$ & $\begin{array}{l}\text { Самопоуздање } \\
\text { у интеракцији }\end{array}$ & $\begin{array}{c}\text { Задовољство } \\
\text { у } \\
\text { интеракцији }\end{array}$ & $\begin{array}{l}\text { Интер- } \\
\text { акција } \\
\text { пажње }\end{array}$ \\
\hline \multirow{2}{*}{ Ниш } & $\mathrm{M}$ & 3,781 & 4,137 & 3,587 & 4,079 & 3,650 \\
\hline & SD & 0,493 & 0,567 & 0,572 & 0,670 & 0,512 \\
\hline \multirow[t]{2}{*}{ Крагујевац } & $\mathrm{M}$ & 3,759 & 4,214 & 3,783 & 4,275 & 3,489 \\
\hline & SD & 0,601 & 0,666 & 0,596 & 0,802 & 0,736 \\
\hline Нови & $\mathrm{M}$ & 3,891 & 4,204 & 3,860 & 4,216 & 3,773 \\
\hline Пазар & SD & 0,485 & 0,523 & 0,569 & 0,624 & 0,637 \\
\hline \multirow{2}{*}{ К. Митровица } & $\mathrm{M}$ & 3,788 & 4,105 & 3,836 & 4,276 & 3,706 \\
\hline & $\mathrm{SD}$ & 0,503 & 0,581 & 0,564 & 0,591 & 0,522 \\
\hline \multirow[t]{2}{*}{ Укупно } & $\mathrm{M}$ & 3,801 & 4,161 & 3,751 & 4,202 & 3,653 \\
\hline & SD & 0,521 & 0,585 & 0,584 & 0,678 & 0,606 \\
\hline $\mathrm{F}$ & & 1,290 & 0,873 & 5,882 & 2,414 & 4,167 \\
\hline $\mathrm{p}$ & & 0,277 & 0,455 & 0,001 & 0,066 & 0,006 \\
\hline
\end{tabular}

Статистичка значајност на нивоу целокупног узорка студената у односу на варијаблу Универзитет потврђена је у две димензије: самопоуздање у интеракцији $(\mathrm{F}=2,41, \mathrm{p}=0,001)$ и усредсређеност у интеракцији $(\mathrm{F}=4,16, \mathrm{p}=0,006)$. Испитаници који похађају Универзитет у Новом Пазару имају највише скорове на димензији самопоуздање у интеракцији $(\mathrm{M}=3,86)$, док најнижи скор имају испитаници који похађају нишки универзитет $(\mathrm{M}=3,58)$. Новопазарски студенти имају и највише скорове на димензији усредсређеност у интеракцији $(\mathrm{M}=3,77)$, док студенти који похађају Универзитет у Крагујевцу на тој димензији имају најнижи скор $(\mathrm{M}=3,48)$.

Повезаност промене места боравка у току студија са интеркултуралном осетљивошћу студента испитивана је Т-тестом за велике независне узорке. Испитивано је да ли постоји разлика између испитаника који су мењали место боравка и студената који нису, у односу на димензије Скале интеркултуралне осетљивости. Резултати су приказани у Табели 5. 
Табела 5. Димензије скале интеркултуралне осетљивости и повезаност са променом места боравка током студија

\begin{tabular}{lccccccc}
\hline & & $\mathrm{N}$ & $\mathrm{M}$ & $\mathrm{SD}$ & $\mathrm{t}$ & $\mathrm{df}$ & $\mathrm{p}$ \\
\hline Ангажованост у & Да & 119 & 3,812 & 0,492 & \multirow{2}{*}{0,258} & \multirow{2}{*}{447} & \multirow{2}{*}{0,797} \\
интеракцији & $\mathrm{He}$ & 330 & 3,798 & 0,533 & & & \\
\hline Поштовање културолошких & Да & 119 & 4,204 & 0,550 & \multirow{2}{*}{0,921} & \multirow{2}{*}{447} & \multirow{2}{*}{0,358} \\
разлика & $\mathrm{He}$ & 330 & 4,147 & 0,599 & & & \\
\hline Самопоуздање у & Да & 119 & 3,746 & 0,595 & \multirow{2}{*}{0,113} & 447 & \multirow{2}{*}{0,910} \\
интеракцији & $\mathrm{He}$ & 330 & 3,753 & 0,583 & & & \\
\hline Задовољство у интеракцији й & Да & 119 & 4,179 & 0,682 & \multirow{2}{*}{0,474} & \multirow{2}{*}{447} & \multirow{2}{*}{0,635} \\
& $\mathrm{He}$ & 330 & 4,214 & 0,679 & & & \\
\hline Усредсређеност у & Да & 119 & 3,739 & 0,568 & \multirow{2}{*}{1,826} & \multirow{2}{*}{447} & \multirow{2}{*}{0,069} \\
интеракцији & $\mathrm{He}$ & 330 & 3,621 & 0,619 & & & \\
\hline
\end{tabular}

Статистичка значајност овог теста изнад је граничне вредности од 0,05 , те је закључак да промена места боравка не утиче на разлике у интеркултуралној осетљивости студената одабраног узорка.

Као једно од истраживачких питања постављено је и то да ли број чланова у породици има утицај на интеркултуралну осетљивост студената. Пирсоновим коефицијентом корелације утврђивано је да ли је број чланова породице у статистички значајној вези са димензијама Скале интеркултуралне осетљивости. Резултати су приказани у Табели 6.

Табела 6. Димензије скале интеркултуралне осетљивости и број чланова у породици

\begin{tabular}{lcr}
\hline \multirow{2}{*}{ Ангажованост у интеракцији } & $\mathrm{r}$ & $-0,047$ \\
\hline \multirow{2}{*}{ Поштовање културолошких разлика } & $\mathrm{p}$ & 0,319 \\
\hline \multirow{2}{*}{ Самопоуздање у интеракцији } & $\mathrm{p}$ & 0,080 \\
\hline \multirow{2}{*}{ Задовољство у интеракцији } & $\mathrm{r}$ & $-0,063$ \\
\hline \multirow{2}{*}{ Усредсређеност у интеракцији } & $\mathrm{r}$ & 0,180 \\
\hline
\end{tabular}

На основу израчунатих вредности, постоји статистички значајна негативна повезаност $(\mathrm{r}=-0,096, \mathrm{p}=0,041)$ димензије задовољство у интеракцији и броја чланова у породици. Коефицијент корелације је негативан, што нас упућује на закључак да што је породица многобројнија, то је скор на димензији задовољство у интеракцији нижи. Негативна повезаност између интеркултуралне осетљивости и интеракције задовољства указује на то да што је виша интеркултурална осетљивост, то је задовољство у интеракцији нижа и обратно. За пре- 
остале четири димензије интеркултуралне осетљивости није потврђена статистичка значајност.

Степен прихватања димензија Скале интеркултуралне осетљивости и стандарда домаћинста у којима живе студенти испитана је Једнофакторском анализом варијансе (ANOVA), а подаци су приказан у Табели 7.

Табела 7. Димензије скале интеркултуралне осетљивости и стандард домаћинства

\begin{tabular}{|c|c|c|c|c|c|c|}
\hline & & $\begin{array}{l}\text { Ангажованост } \\
\text { у интеракцији }\end{array}$ & $\begin{array}{c}\text { Поштовање } \\
\text { култу- } \\
\text { ролошких } \\
\text { разлика } \\
\end{array}$ & $\begin{array}{c}\text { Самопо- } \\
\text { уздање у } \\
\text { интеракцији }\end{array}$ & $\begin{array}{c}\text { Задо- } \\
\text { вољство у } \\
\text { интеракцији }\end{array}$ & $\begin{array}{c}\text { Усредсре- } \\
\text { Ђеност у } \\
\text { интеракцији }\end{array}$ \\
\hline \multirow[t]{2}{*}{ У просеку } & $\mathrm{M}$ & 3,836 & 4,195 & 3,781 & 4,260 & 3,676 \\
\hline & SD & 0,523 & 0,570 & 0,586 & 0,611 & 0,604 \\
\hline \multirow{2}{*}{$\begin{array}{l}\text { Испод } \\
\text { просека }\end{array}$} & $M$ & 3,816 & 4,187 & 3,661 & 4,259 & 3,673 \\
\hline & SD & 0,552 & 0,481 & 0,588 & 0,506 & 0,525 \\
\hline \multirow{2}{*}{$\begin{array}{l}\text { Изнад } \\
\text { просека }\end{array}$} & $\mathrm{M}$ & 3,924 & 4,166 & 3,882 & 4,216 & 3,765 \\
\hline & SD & 0,413 & 0,582 & 0,526 & 0,778 & 0,583 \\
\hline \multirow{2}{*}{$\begin{array}{l}\text { Не знам / } \\
\text { Не могу да } \\
\text { оценим }\end{array}$} & $\mathrm{M}$ & 3,637 & 4,039 & 3,660 & 3,984 & 3,530 \\
\hline & SD & 0,506 & 0,673 & 0,587 & 0,862 & 0,649 \\
\hline \multirow[t]{2}{*}{ Укупно } & $\mathrm{M}$ & 3,801 & 4,161 & 3,751 & 4,202 & 3,653 \\
\hline & SD & 0,521 & 0,585 & 0,584 & 0,678 & 0,606 \\
\hline $\mathrm{F}$ & & 4,158 & 1,662 & 1,937 & 3,993 & 1,795 \\
\hline $\mathrm{p}$ & & 0,006 & 0,174 & 0,123 & 0,008 & 0,147 \\
\hline
\end{tabular}

Статистичка значајност потврђена је на димензијама: ангажованост у интеракцији $(\mathrm{F}=4,158, \mathrm{p}=0,006)$, задовољство у интеракцији $(\mathrm{F}=3,993, \mathrm{p}=0,008)$. Испитаници који се изјашњавају да је њихов породични стандард изнад просека имају највиши скор на димензији ангажованост у интеракцији $(\mathrm{M}=3,92)$, док студенти који су неодлучни имају најнижи скор на овој димензији $(\mathrm{M}=3,63)$, као и на димензији задовољство у интеракцији $(\mathrm{M}=3,99)$, док остали студенти имају сличне скорове на овој димензији.

Истраживачко питање да ли различита места становања током студија утичу на различите процене димензија интеркултуралне осетљивости тестирано је Једнофакторском анализом варијансе (ANOVA).

Статистичка значајност није забележена ни на једној димензији интеркултуралне осетљивости студената. Дакле, може се потврдити на основу добијених вредности да место становања у току студија не утиче на повишену или смањену интеркултуралну осетљивост студента. 
Табела 8. Димензије скале интеркултуралне осетљивости и место становањ а испитаника

\begin{tabular}{|c|c|c|c|c|c|c|}
\hline & & $\begin{array}{c}\text { Ангажова- } \\
\text { ност у } \\
\text { интеракцији }\end{array}$ & $\begin{array}{c}\text { Поштовање } \\
\text { културо- } \\
\text { лошких } \\
\text { разлика }\end{array}$ & $\begin{array}{c}\text { Самопо- } \\
\text { уздање у } \\
\text { интеракцији }\end{array}$ & $\begin{array}{c}\text { Задо- } \\
\text { вољство } \\
\text { у интер- } \\
\text { акцији }\end{array}$ & $\begin{array}{c}\text { Усредсре- } \\
\text { ђеност у } \\
\text { интеракцији }\end{array}$ \\
\hline \multirow{2}{*}{$\begin{array}{l}\text { Породични } \\
\text { дом }\end{array}$} & $\mathrm{M}$ & 3,841 & 4,145 & 3,799 & 4,147 & 3,713 \\
\hline & SD & 0,521 & 0,607 & 0,591 & 0,690 & 0,606 \\
\hline \multirow{2}{*}{ Подстанар } & $\mathrm{M}$ & 3,794 & 4,215 & 3,720 & 4,254 & 3,608 \\
\hline & SD & 0,530 & 0,549 & 0,579 & 0,679 & 0,632 \\
\hline \multirow{2}{*}{$\begin{array}{l}\text { Студентски } \\
\text { дом }\end{array}$} & $\mathrm{M}$ & 3,727 & 4,074 & 3,732 & 4,249 & 3,612 \\
\hline & SD & 0,506 & 0,615 & 0,588 & 0,630 & 0,540 \\
\hline \multirow[t]{2}{*}{ Укупно } & $M$ & 3,802 & 4,161 & 3,755 & 4,209 & 3,653 \\
\hline & SD & 0,523 & 0,587 & 0,585 & 0,676 & 0,607 \\
\hline$F$ & & 1,359 & 1,721 & 0,909 & 1,335 & 1,597 \\
\hline $\mathrm{p}$ & & 0,258 & 0,180 & 0,404 & 0,264 & 0,204 \\
\hline
\end{tabular}

У Табели 9 приказана је повезаност социодемографских варијабли са димензијама скале интеркултуралне осетљивости.

Табела 9. Повезаност сочиодемографских варијабли са димензијама скале интеркултурне осетљивости

\begin{tabular}{|c|c|c|c|c|c|c|}
\hline & & $\begin{array}{c}\text { Ангажо- } \\
\text { ваност } \\
\text { у интер- } \\
\text { акцији } \\
\end{array}$ & $\begin{array}{c}\text { Поштовање } \\
\text { културо- } \\
\text { лошких } \\
\text { разлика } \\
\end{array}$ & $\begin{array}{c}\text { Самопо- } \\
\text { уздање } \\
\text { у интер- } \\
\text { акцији } \\
\end{array}$ & $\begin{array}{c}\text { Задо- } \\
\text { вољство } \\
\text { у интер- } \\
\text { акцији } \\
\end{array}$ & $\begin{array}{c}\text { Усредсре- } \\
\text { ђеност у } \\
\text { интер- } \\
\text { акцији } \\
\end{array}$ \\
\hline \multirow{2}{*}{ Универзитет } & $\mathrm{r}$ & 0,031 & $-0,015$ & $0,171^{* *}$ & $0,099^{*}$ & 0,074 \\
\hline & $\mathrm{p}$ & 0,505 & 0,743 & 0,000 & 0,036 & 0,114 \\
\hline Промена места & $\mathrm{r}$ & $-0,012$ & $-0,044$ & 0,005 & 0,022 & $-0,086$ \\
\hline боравка & $\mathrm{p}$ & 0,797 & 0,358 & 0,910 & 0,635 & 0,069 \\
\hline Број чланова & $\mathrm{r}$ & $-0,047$ & $-0,080$ & $-0,063$ & $-0,096^{*}$ & 0,057 \\
\hline у породици & $\mathrm{p}$ & 0,319 & 0,090 & 0,180 & 0,041 & 0,231 \\
\hline Стандард & $\mathrm{r}$ & $-0,124^{* * *}$ & $-0,098^{*}$ & $-0,063$ & $-0,149^{* * *}$ & $-0,075$ \\
\hline домаћинства & $\mathrm{p}$ & 0,008 & 0,038 & 0,181 & 0,002 & 0,111 \\
\hline Место становања & $\mathrm{r}$ & $-0,077$ & $-0,020$ & $-0,052$ & 0,066 & $-0,073$ \\
\hline током студија & $\mathrm{p}$ & 0,102 & 0,669 & 0,269 & 0,161 & 0,122 \\
\hline
\end{tabular}

Пирсоновим коефицијентом корелације испитивано је да ли су скорови на скали интеркултурне осетљивости у статистичкој повезаности са социодемографским варијаблама. Резултати показују да је ангажованост у интеракцији у статистички значајној негативној корелацији са стандардом домаћинства $(\mathrm{r}=-0,124, \mathrm{p}=0,008)$, као и да је димензија поштовање културолошких разлика у статистички значајној негативној корелацији са варијаблом стандард домаћинства $(\mathrm{r}$ $=-0,098, \mathrm{p}=0,038)$. Димензија Скале самопоуздање у интеракцији је 
у статистички значајној позитивној корелацији са универзитетом са кога испитаници долазе $(\mathrm{r}=0,171, \mathrm{p}=0,000)$. Димензија скале задовољство у интеракцији у статистички значајној позитивној корелацији је са универзитетом са кога испитаници долазе $(\mathrm{r}=0,099, \mathrm{p}=$ $0,036)$, док је у статистички значајној негативној корелацији са варијаблама стандард домаћинства $(\mathrm{r}=-0,149, \mathrm{p}=0,002)$ и број чланова породице $(\mathrm{r}=-0,096, \mathrm{p}=0,041)$. Код димензије Скале интеркултуралне осетљивости - усредсређеност у интеракцији, није потврђена статистички значајна повезаност ни са једном социодемографском варијаблом истраживања.

У односу на добијене вредности за испитиване варијабле, код појединих је добијена статистички значајна корелација са димензијама скале, и исте су ушле су униваријантан регресиони модел.

Табела 10. Предикиија скора на димензијама скале интеркултурне осетљивости

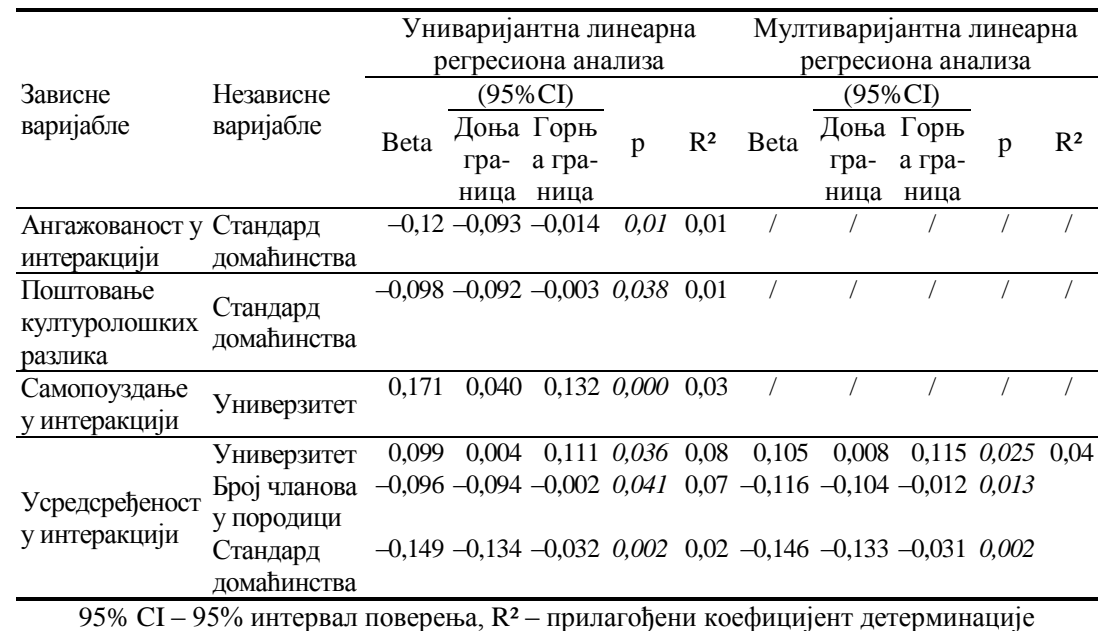

Стандард домаћинства статистички је значајан предиктор димензије ангажованост у интеракцији $(\beta:-0,12(-0,093--0,014) . \quad \mathrm{P}=$ $0,01)$. Ова варијабла сама објашњава само $1 \%$ варијансе зависне променљиве. Стандард домаћинства показује статистички значајан допринос и објашњењу димензије поштовање културолошких разлика ( $\beta$ : -0,098 (-0,092 - -0,003). p = 0,038), објашњавајући 1\% варијансе,

Статистички значајан утицај варијабле универзитет који студенти похађају потврђен је на димензији самопоуздање у интеракцији $(\beta: 0,171(0,040-0,132), p=0,000)$, Задовољство у интеракцији једина је димензија Скале на којој су три независне варијабле показале утицај, Универзитет сам објашњава 3,6\% варијансе зависне променљиве $(\beta: 0,099(0,004-0,111), p=0,036)$, Код броја чланова у поро- 
дици добијене су следеће вредности $(\beta:-0,096(-0,094--0,002), \mathrm{p}=$ $0,041)$, док код стандарда домаћинства износе $(\beta:-0,149(-0,134--$ $0,032), \mathrm{p}=0,002)$. Како су ове три варијабле показале статистички значајан допринос објашњењу зависне варијабле, из тог разлога су ове три независне варијабле ушле у мултиваријантни регресиони модел. Заједно три независне објашњавају 4\% варијансе зависне променљиве.

У мултиваријантном регресионом моделу, заједно за поменуте предикторе, највећи утицај на интеркултуралну осетљивост студената показује социодемографска варијабла стандард домаћинства ( $\beta$ : $0,146(-0,133--0,031), p=0,002)$, затим број чланова у породици ( $\beta$ : $-0,116(-0,104--0,012), p=0,013)$ и на крају универзитет $(\beta: 0,105$ $(0,008-0,115), \mathrm{p}=0,025)$.

\section{ДИСКУСИЈА И ЗАКљУЧЦИ}

У зависности од друштвеног и образовног контекста, улоге које појединци заузимају, околности у којима живе, уче и развијају се, те друге бројне различитости могу бити извори проблема или постати ризница богаћења, разумевања и прихватања искустава културолошки различитих особа, група и њихових вредности. Факултети и њихови програми би у том смислу требало да доприносе процесу боље усмерености и свесности студената о значају интеркултуралне осетљивости и активног суживота у друштвеној заједници. Један од услова развоја огледа се у непрестаној интеракцији, размени искустава, уважавања и разумевања културолошких разлика, али на начине који се предлажу, а то су: константна размена искустава студената о другим културама, гледањем филмова и стварањем рефлексија о њима. На нивоу наше земље, може се приметити да образовни програми иницијалног образовања углавном не садрже довољно тема из подручја интеркултуралног образовања, док боравак у мултиетничком окружењу за време студирања сам по себи не мора бити услов за развијање ових компетенција.

У спроведеном истраживању анализиране су релације између процењеног степена развијености интеркултуралне осетљивости студената и одабраних социодемографских варијабли: универзитета испитаника, промене места боравка током студија, стандарда домаћинства у односу на просек у Србији, место становања током студија и просечан број чланова у породици. Добијени резултати потврдили су повезаност појединих социодемографских детерминанти са проценама студената на димензијама скале интеркултуралне осетљивости.

Пет одређених димензија интеркултуралне осетљивости, према проценама студената, рангирано је на следећи начин: задовољство у интеракцији, поштовање културолошких разлика, ангажова- 
ност у интеракцији, самопоуздање у интеракцији и усредсређеност у интеракцији. Вредности за све димензије су изнад 3 , чиме су потврђени релативно високи резултати на свакој.

Резултати су такође показали да код варијабле универзитет постоји статистичка значајност у проценама интеркултуралне осетљивости, јер студенти Универзитета у Новом Пазару на димензијама Скале: самопоуздање у интеракцији и усредсређеност у интеракцији имају највише скорове. Код димензије самопоуздање у интеракцији према проценама испитаника најниже скорове имају студенти Универзитета у Нишу, док су код димензије усредсређеност у интеракцији процене студената Универзитета из Крагујевца са најнижим скоровима. Упркос поменутим налазима иностраних аутора (Bok, 2006; Logašenko, 2015; Deardorff, 2011) да боравак студената у кампусима интеркултуралног састава не утиче на њихов степен интеркултуралности, добијени резултати овог истраживања показују да степен интеркултуралне осетљивости студената који студирају у мултикултуралној средини (у Новом Пазару) утиче на бољу перцепцију личне интекултуралне осетљивости на појединим димензијама. Резултати истраживања се могу посматрати као показатељ да живот у мултикултуралној заједници може бити позитиван предиктор интеркултуралне осетљивости, јер живот са људима из других култура доприноси развијању интеркултуралне осетљивости и значајно одређује понашања појединца. Добијени резултати су значајни из аспекта сагледавања ресурса који би се могли ставити у функцију оснаживања интеркултуралних компетенција, пре свега интеркултуралне осетљивости.

На једној од пет истраживаних димензија интеркултуралне осетљивости, код задовољства у интеракцији, добијена је статистички негативна повезаност $(\mathrm{r}=-0,096, \mathrm{p}=0,041)$ са бројм чланова у породици испитаника. Код ове димензије већи број чланова у породици утиче на нижи степен интеркултуралне осетљивости студената, што се такође може довести у везу са стандардом домаћинства.

Највише скорове код димензија ангажованост у интеракцији и задовољство у интеракцији показали су студенти који су стандард својих породица проценили као изнад просека. Претпоставка је да ова група испитаника има веће могућности за путовања и остварење контаката са људима из других култура, те су зато и скорови на појединим димензијама интеркултуралне осетљивости виши. Смештај у којем живе студенти за време студија (сопствени дом, подстанари или студентски дом) не указује на статистички значајне разлике у проценама интеркултуралне осетљивости.

Резултати спроведеног истраживања потврђују да одређене социодемографске варијабле представљају значајније предикторе утицаја на процене интеркултуралне осетљивости студената, а то су: 
стандард домаћинства ( $\beta$ : $-0,146(-0,133--0,031) . \quad \mathrm{p}=0,002)$, затим број чланова у породици $(\beta:-0,116(-0,104--0,012), p=0,013)$, и универзитет $(\beta: 0,105(0,008-0,115) . p=0,025)$. Поменуте три варијабле показале су статистички значајан допринос објашњењу зависне, заједно објашњавају 4\% варијансе зависне променљиве.

Као практичне импликације спроведеног истраживања могу се издвојити препоруке конкретно за високошколску наставу, посебно за факултете који школују кандидате за рад у образовању, за увођењем студијских програма или програмских садржаја, којима би се студенти припремали за интеркултуралне изазове у учионицама и у друштву. Високошколске установе, кроз програме засноване на интеркултуралним садржајима, могу компензовати и надокнадити запажене негативне утицаје, настале услед лошег стандарда домаћинства у којима живе студенти, или можда и слабијих економских могућности (породице са већим бројем деце), и на одређен начин надоместити уочене недостатке, другачијим опхођењем са овим групама студената.

Будућа истраживања потребно је усмерити на повезивање интеркултуралне осетљивости студената са другим варијаблама и сачинити целовитији приступ у развоју ове врсте компетенција, посебно кроз формални образовни систем. Такође, било би значајно квалитативно испитати интеркултуралну компетентност студената у мултикултуралним срединама и њихова понашања у смислу остваривања заједништва и стремљења ка стварању мултикултуралних вредности.

\section{ЛИТЕРАТУРА}

Bennett, M. J. (2004). Becoming Interculturally Competent. In J. Wurzel (Ed.), Toward multiculturalism: A reader in multiculturaleducation (pp. 62-77). Newton, MA: Intercultural Resource Corporation

Boneta, Ž. Ivković, Ž. Lacmanović, T. (2013). Interkulturalne kompetencije odgojiteljica i socijalna distanca. [Intercultural Competences of Kindergarten Teachers and Social Distance]. Školski vjesnik 62(4), 479-494.

Bok, D. (2006). Our Underachieving Colleges: A Candid Look at How Much Students Learn and Why They Should Be Learning More. Princeton: Princeton University Press

Chen, G. M., \& Starosta, W.J. (2000). The development and validation of the Intercultural Sensitivity Scale. Human Communication, 3, 1-15.

Chen, G.M., \& Starosta, W. J. (1999). A review of the concept of intercultural awareness. Human Communication, 2, 27-54.

Черняк, Н. В. (2015). Межкультурная компетенция »исмежные термин ывпонятийномап паратемеж культурной дидактики. Вестник Новосибирского государственного университета. Серия: Лингвистика $и$ межкультурная коммуникация, 13(2), 68-77.

Deardorff, D. K. (2004). The identification and assessment of intercultural competence as a student outcome of internationalization at institutions of higher education in the 
United States. Doctoral Dissertation. Raleigh, North Carolina: Faculty of North Carolina State University.

Deardorff, D. K. (2006). The Identification and Assessment of Intercultural Competence as a Student Outcome of internationalization at Institutions of Higher Education in the United States." Journal of Studies in International Education, 10(3), 241-266.

Deardorff, D.K. (2011). Assessing intercultural competence. New directions for institutional research, 149, 65-79.

Fantini, A. E. (2000). A central concern: Developing intercultural competence. SIT Occasional Papers Series, 1, 25-42.

Fritz, W., Möllenberg, A. (2002). Measuring Intercultural Sensitivity in Different Cultural Contexts. Intercultural Communication Studies, 11(2), 165-176.

Golub, A. (2014). Effects of German Language Teacher Professional Development on Pupils' Learning Outcomes in Intercultural Competence, Ceps Journal, 4(4), 75-98.

Hrvatić, N., Piršl, E. (2007). Interkulturalne kompetencije učitelja. [Intercultural Competences of Teachers] U: N. Babić (ur.). Kompetencije $i$ kompetentnost učitelja. Osijek: Učiteljskifakultet, 221-230.

Јовановић, Б., Качапор, С. (2016) Васпитање за међунационалну толеранцију и сарадњу. [Education for inter-ethnic tolerance and cooperation]. Теме, 1, 351-364.

Корниенко, А.В. Ерофеева, В. Г. (2017) Межкультурная сенситивность и этническая идентичность в поликультурной среде вуза, Молодой учёный, Меж дународный научный журнал, 19(153), 279-282.

Логашенко, Ю. А. (2015). Межкультурная сенситивность студентов в полиэтничной среде, Диссертация, Санкт Петербур: Государственный Университет.

Ouellet, F. (2002). L'éducation interculturelle et l'éducation à la citoyenneté. Quelques pistes pour s'orienter dans la diversité des conceptions. VEI Enjeux, 129, 146-167.

Park, R. E. (1924). The concept of social distance: As applied to the study of racial attitudes and racial relations, Journal of Applied Sociology, 8, 339- 334.

Petrović, D., Starčević, J., Chen, G., Komneninić, D. (2015). Intercultural Sensitivity Scale: Proposal for a Modified Serbian Version. Psihologija, 48(3), 199-212. DOI: 10.2298/PSI1503199P

Petrović. D., Jokić, Gošović, P., Čekić Marković, J. (2016). Analiza zakonske i strateške regulative u oblasti interkulturalnog obrazovanja u Srbiji. [Analysis of Legal and Strategic Regulations in the Area of Intercultural Education in Serbia] (19-45). U: D. Petrović i T. Jokić (Ur.). Interkulturalno obrazovanje u Srbiji. Regulativni okvir, stanje i mogućnosti za razvoj. [Intercultural Education in Serbia. Regulatory Framework, Conditions and Possibilities for Development]. Beograd: Centar za obrazovne politike.

Piršl, E. (2014). (Re)definicija pojma kompetencije i interkulturalne kompetencije. [(Re)definition of the Concept of Competence and Intercultural Competence]. U: N. Hrvatić (ur.) Interkulturalno obrazovanje i europske vrijednosti. [Intercultural Education and European Values]. Filozofski fakultet u Zagrebu, Visoka škola, $47-68$.

Почебут Л. Г. (2007). Теория межкультурной коммуникативной компетентности // Вестник СПбГУ. Серия 6. Политология. Международные отношения, № 3. URL: http://cyberleninka.ru/article/n/teoriya-mezhkulturnoykommunikativnoykompetentnosti.

Sarwari, A, Abdul Wahab, M. (2017). Study of the relationship between intercultural sensitivity and intercultural communication competence among international postgraduate students: A case study at University Malaysia Pahang. Media \& Communication studies vol 3. 1. http://dx.doi.org/10.1080/23311886.2017. 1310479. 


\title{
SOCIODEMOGRAPHIC DETERMINANTS AS PREDICTORS OF INTERCULTURAL SENSITIVITY OF STUDENTS
}

\author{
Igor Đurić ${ }^{1}$, Daliborka Popović ${ }^{2}$, Aleksandra Anđelković ${ }^{3}$ \\ ${ }^{1}$ University in Priština Kosovska Mitrovica, Faculty of Philosophy, Serbia \\ ${ }^{2}$ State University of Novi Pazar, Faculty of Science, Serbia \\ ${ }^{3}$ University of Niš, Pedagogical Faculty in Vranje, Serbia
}

\section{Summary}

Specific social context is seen not only as a determiner of the notion of interculturality, but also as a variable of the utmost influence for the development of an individual's intercultural sensitivity. Therefore, when understanding the influence of certain dimensions of intercultural sensitivity, it is necessary to take into consideration the social context in which individuals live, namely students. The making and improving of relations and interpersonal understanding between members of different cultures and social groups is emphasized as the basic goal of intercultural competencies development.

As previous research indubitably shows, when analyzing the factors of the students' intercultural sensitivity development, considering the individual's social context which creates community's system of values is of importance, and thus it is valuable for educational policies. Therefore, the research goal was focused on determining the degree of development of the students' intercultural sensitivity in relation to the sociodemographic variables. The research was conducted on an appropriate sample of 452 students from four universities in Serbia, using the Intercultural Sensitivity Scale.

The obtained results on the students, the intercultural sensitivity from the research, despite the mentioned results of international authors, have all shown that living in a multicultural environment positively affects the degree of the students' intercultural sensitivity in some dimensions. Thus, the students of the State University of Novi Pazar made higher leaps in two dimensions of intercultural sensitivity: interaction of trust and interaction of attention in comparison to the respondents from other environments. Research results show that lower scores in the dimensions of satisfaction interaction are contributed by a larger number of family members. On the other hand, the family standard that is above average contributes to the highest levels in the dimension of intercultural sensitivity (engagement in interaction). It is supposed that this group of examinees communicates significantly more with people from different cultures; therefore, the levels on certain dimensions of intercultural sensitivity are higher.

The practical implications of the conducted research can be stressed as recommendations, concretely for higher education, especially for faculties which prepare candidates for educational work, so they would introduce courses or programs that prepare students for intercultural challenges in classrooms. 